\title{
Performance analysis and mentoring strategy of fish farmers groups in Muntilan Sub District, Magelang Regency, Central of Java Province
}

\author{
Ina Restuwati ${ }^{1, *}$ Achmad K. A. Munif ${ }^{1}$ \\ ${ }^{1}$ Fisheries Extension Study Program, Jakarta Technical University of Fisheries, Indonesia.
}

\begin{abstract}
The purpose of this research was to identify performance and determine the strategy for improving the performance of fish farmers groups in this area, which has excellent and dominant potential in freshwater aquaculture. There were about 131 fish farmers and 11 fish hatchery and rearing groups from this region's six research sample villages. The identification results of the fishbone diagram analysis showed that the fish farmer group's growth and development, in general, were still low, based on several dominant categories, namely infrastructure, fisheries extension performance, contribution performance, and the interests of fish farmers. In detail, the causes were: 1) insufficient facilities and infrastructure; 2) management in implementing fish farmers groups function has not run optimally; 3) the lack of fisheries extension workers; 4) the lack of contribution among group members; 5) relationship between fish farmers groups and local government institutions was still low; 6) fisheries activities were dominated by certain people; and 7) the interests of the fish farmers to form groups were still low. As the results of the SWOT analysis, the fish farmers group's performance development strategy was carried out by improving the performance of group roles and functions through mentoring and facilitating group activities.
\end{abstract}

\section{Introduction}

Identification was the initial stage of mastering the problem of a particular object and in a specific situation that was recognized as a problem [7]. The issues in Muntilan Sub District related to the performance of fish farmers in freshwater need to be formulated to explore the existing problems and determine the strategy for solving them. In this research, identification activities result become the basis for deciding problem-solving strategies. On the other hand, in group growth and development guidelines, it was explained that seven principles could use as the basis for the growth and development of fish farmers groups, namely the principles of populist and partiality, independence, partnership, and collaboration, gradual and sustainable, participatory and empowerment [15]. So that, there was a close relationship between the problems in the groups, solution strategy, and sustainability of the strengths of the roles and functions of the fish farmers groups [1].

Based on geographic location, Muntilan Sub District was located in the east of Magelang Regency, and it was about $15 \mathrm{~km}$ from the Magelang Regent's Office, with an area of 28.61

* Corresponding author : restuina@gmail.com 
$\mathrm{km}^{2}$. It was approximately 300 meters above sea level [3]. Muntilan Sub District consists of several villages, namely : Tanjung, Sokorini, Sriwedari, Congkrang, Adikarto, Menayu, Keji, Ngawen, Gunungpring, Pucungrejo, Taman Agung, Gondosuli, Sedayu and Muntilan [9]. Research location and Muntilan Sub District map as shown below [6]

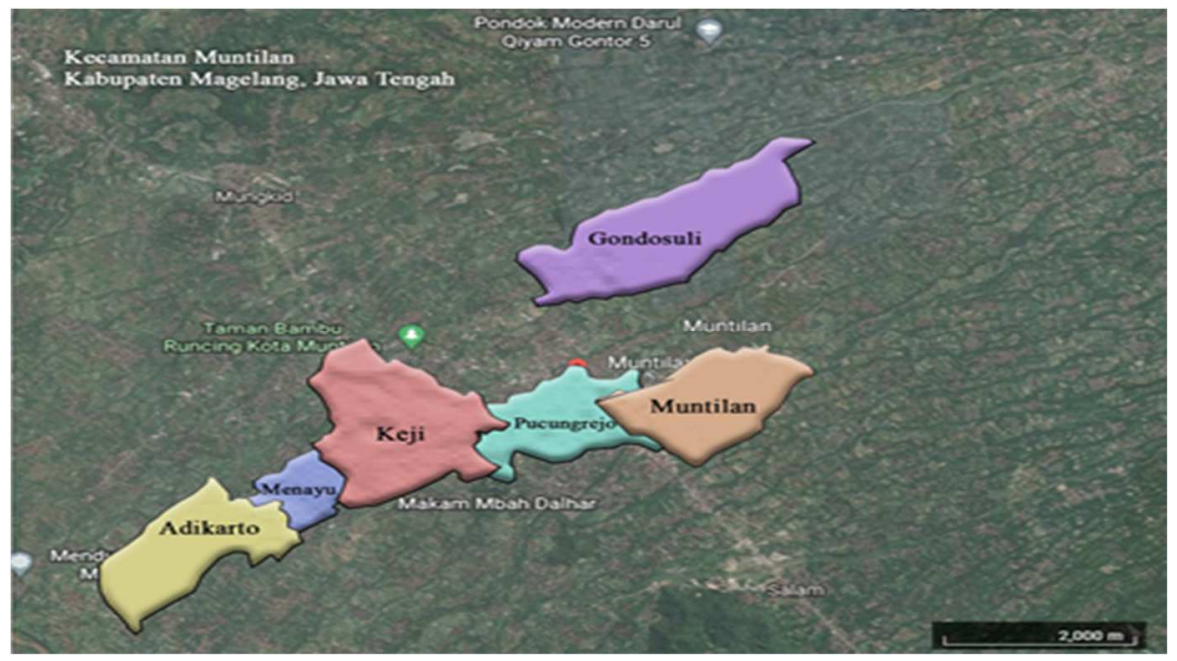

Fig. 1. Research location area

The potential of freshwater fisheries culture in this area was auspicious, considering the natural fisheries resource that supports the development of freshwater fish farming with certain commodities [2]. The natural resource identification results have shown that dominant freshwater fish culture commodities in this area were tilapia and catfish [9]. The majority of the community carried out freshwater fish culture activities by utilizing the yard for fish cultivation, among others, by cultivating fish using tarpaulin ponds, earthen ponds, and wall ponds [18]. The fish farmers carry out planning on technical matters traditionally without any treatment [4]. There were about 131 fish farmers and fisheries entrepreneurs from 6 potential fisheries villages identified in this sub-district. The number consists of groups of fish breeders, enlargement, processing, and marketing of fisheries products [9].

Identification results have shown that several parameters influence the process of growing and developing fish farmers' business in Muntilan Sub District, which will ultimately influence the whole performance of the fish farmers' group's activities. These parameters were generally grouped into several factors such as the infrastructure that have been owned and used by fish farmers, human resource of the fish farmers and fisheries extension workers, the roles and functions of fish farmers groups management, relationships with fisheries supporting institutions, and another activity which related to the interests of the fish farmers groups, and there were the several fish farmers dominate of fisheries business [2].

With this condition, it was necessary to map the fish farmers' problems in this region and correctly identify the factors that hinder the activities of its growing and developing aquaculture farmers groups. More can be known how the fisheries extension system worked in this area. Fishbone diagram analysis was used to identify and understand how the performance of fisheries extension system running in Muntilan Sub District [17], and then used the strengths, weaknesses, opportunities, and threats analysis (SWOT) to determine the strategy of an action plan based on the mapping of aquaculture farmers groups problems [19]. 


\section{Methods}

\subsection{Time, place, and data collection}

This research was conducted from March to May 2020 in Muntilan Sub District, Magelang Regency, by taking samples from six potential fisheries villages in this sub-district, namely Menayu, Gondosuli, Keji, Muntilan, Pucungrejo, and Adikarto. Primary data was collected from respondents in these six samples villages, the population as many as 131 fish farmers [9], that were taken from the results of data collection using questionnaires, as well as direct observations and also from interviews with the fish farmers as respondents in this research [16]. Secondary data were obtained from monthly and annual reports of the Muntilan Sub District office, fisheries extension work plans of this area, annual reports from the Department of Animal Husbandry and Fisheries of Magelang Regency and another institution that related with the fisheries activities of this area, and also the data from online literature. Simple random sampling was used to determine the respondents of this research and did the descriptive processing and analysis data [14],

\subsection{Data analysis}

Analysis of data research using the Ishikawa Method or Fishbone Diagram (Ishikawa, 1989), which was used to determine the factors that influence of how the performance of fisheries extension system running in Muntilan Sub District [17], and the formulation of group improvement strategy was carried out by using strengths weaknesses, opportunities, and threats (SWOT) analysis.

It was based on a logic that can maximize strengths and opportunities, but at the same time, can be minimized weaknesses and threats. Strategy formulation was carried out by first creating a matrix of internal factor analysis summary (IFAS) and external factor analysis summary (EFAS). The IFAS matrix was used to identify the internal strategic factors of strengths and weaknesses. At the same time, the EFAS matrix was used to determine the external strategy factors of opportunities and threats [5].

\section{Result and discussion}

\subsection{Fishbone analysis results}

The fishbone analysis showed that four parameters determine the development of fish farmers groups, namely infrastructure, implementation of fisheries mentoring, the contribution of fish farmers, and the interests of fish farmers [8,17].

The factors that influence performance were :1) infrastructure related to fish farming business such as limited number of ponds and traditional pond buildings, consumable production facilities that require pretty high costs, 2) group management has not run optimally due to weaknesses in knowledge so that the skills and attitudes of fish farmers were still low, 3) lack of knowledge of fisheries mentoring, transfer of fisheries technology to improve knowledge, skills and attitudes of fish farmers was hampered, 4) lack of contribution members in groups, where was the group as a place for collaboration, also as a fisheries production unit, 5) the relationship between groups of fish farmers and local government institutions was still low due to the limited facilitation of extension fisheries workers, as well as financial and marketing support was still lacking, 6) interest in fish farmers was still low to be established [2], 7) fisheries business patterns, which both of fish hatcheries and fish 
rearing, those were dominated by sure fish farmers, and it was give the destructive impact for development of new growing and developing aquaculture businesses [15].

In addition, the low performance of fish farmers in developing groups was also caused by the weaknesses of group management in carrying out roles and functions so that group members did not work together to support the groups [8] actively.

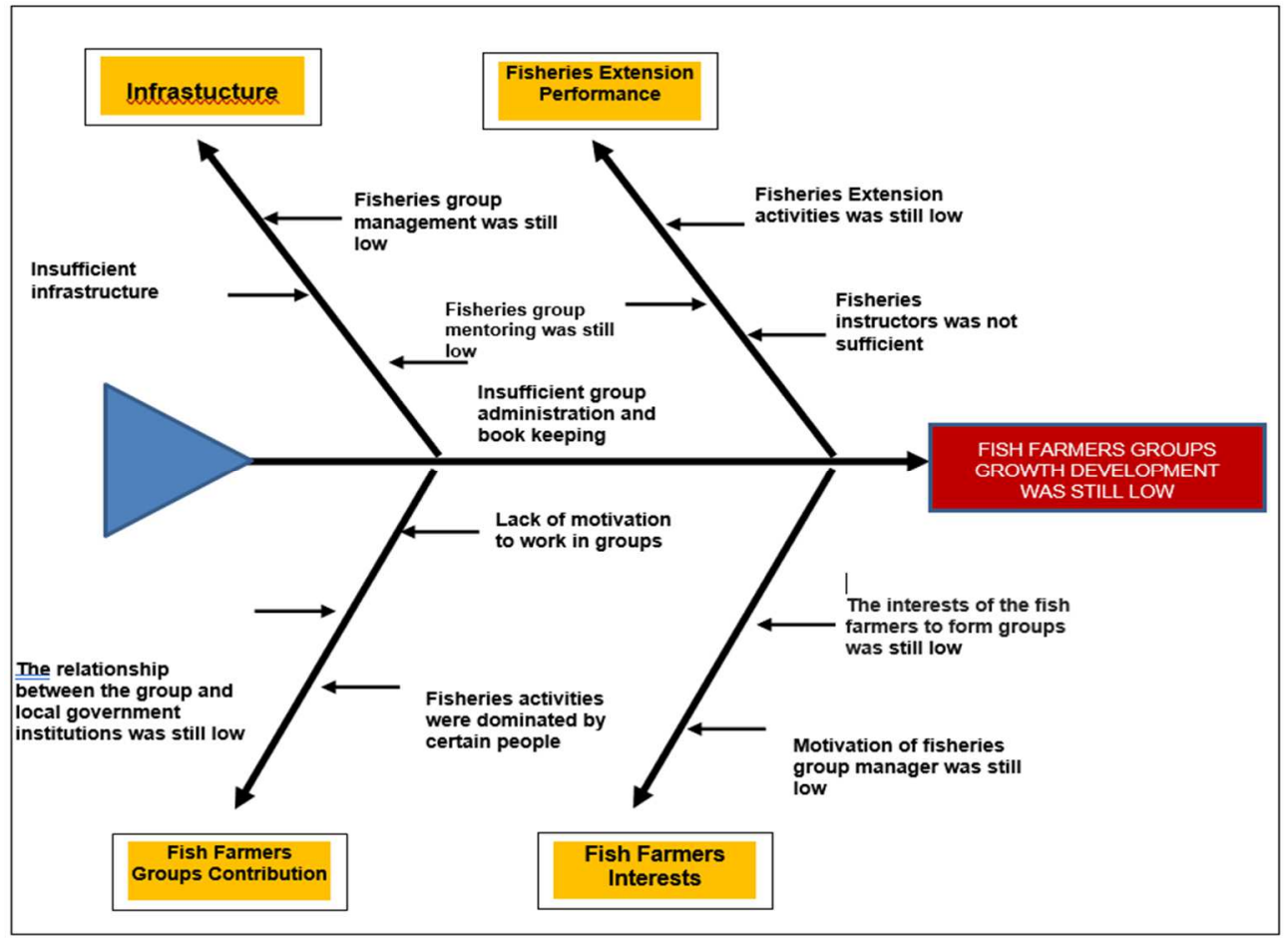

Fig. 2. Fishbone diagram analysis

\subsection{SWOT analysis results to improve fisheries extension performance groups}

\subsubsection{Internal Factor Analysis Summary (IFAS)}

The strategy for improving the performance of the fish farmers groups needs to be formulated to provide solutions to the problems identified through fishbone analysis. The strategy was developed based on the results of an evaluation of internal and external factors to improve the performance of the fish farmers groups in Muntilan Sub District, Magelang Regency [17].

From the internal analysis results, it can be identified that there were five strengths factors and five weaknesses as presented in the internal factor analysis summary matrix (IFAS). In the IFAS matrix, a value of 3,06 was obtained (Table 1). This indicates that the internal condition of performance of the fish farmers groups in this region has many strengths factors $[5]$. 
Table 1. Internal Factor Analysis Summary (IFAS).

\begin{tabular}{|c|c|c|c|c|}
\hline \multicolumn{2}{|r|}{ Internal Factors Strategic (IFAS) } & Weight & Rating & Score \\
\hline \multicolumn{2}{|r|}{ Strengths } & & & \\
\hline 1. & Potential for human resource development is quite high & 0,06 & 3 & 0,18 \\
\hline 2. & Sufficient number of main actors to be developed & 0,12 & 4 & 0,48 \\
\hline 3. & A lot of fisheries groups have been formed & 0,09 & 5 & 0,45 \\
\hline 4. & Sufficient experience in the fisheries business of the main actors & 0,12 & 3 & 0,36 \\
\hline 5. & The area for fish farming development is still wide & 0,12 & 4 & 0,48 \\
\hline \multicolumn{2}{|r|}{ Weaknesses } & & & \\
\hline 1. & Inadequate infrastructure & 0,09 & 2 & 0,18 \\
\hline 2. & $\begin{array}{l}\text { Management, group administration, motivation to cooperate and } \\
\text { participation are still low }\end{array}$ & 0,12 & 2 & 0,24 \\
\hline 3. & The number of extension workers are not sufficient & 0,12 & 3 & 0,36 \\
\hline 4. & Interest in groups are still low & 0,09 & 2 & 0,18 \\
\hline \multirow[t]{2}{*}{5.} & $\begin{array}{l}\text { Relationship between groups and institutions supporting fisheries is } \\
\text { still low }\end{array}$ & 0,06 & 2 & 0,12 \\
\hline & Total & $\mathbf{1 , 0 0}$ & & 3,06 \\
\hline
\end{tabular}

\subsubsection{External Factor Analysis Summary (EFAS)}

The external factors analysis results identified five opportunities factors and five threats (Table 2). The EFAS matrix showed a value of 2,62, which means that the performance of the fish farmers groups must be able to take advantage of enormous opportunities and minimize the threats space [5].

Table 2. External Factor Analysis Summary (EFAS).

\begin{tabular}{|c|c|c|c|c|}
\hline & External Factors Strategic (EFAS) & Weight & Rating & Score \\
\hline \multicolumn{5}{|c|}{ Opportunities } \\
\hline 1. & Consumer interests to the fisheries business results were quite high & 0,10 & 3 & 0,30 \\
\hline 2. & $\begin{array}{l}\text { Access to increase knowledge and skills in fisheries technology for the } \\
\text { fish fammers were wide open }\end{array}$ & 0,14 & 4 & 0,56 \\
\hline 3. & Financial and marketing institutions support were quite high & 0,10 & 3 & 0,30 \\
\hline 4. & Commodities of freshwater fish produced were easy to obtain & 0,10 & 2 & 0,20 \\
\hline 5. & Collaboration network between many fisheries groups were open well & 0,10 & 2 & 0,20 \\
\hline \multicolumn{5}{|c|}{ Threats } \\
\hline 1. & Group independence was hampered by regulation & 0,07 & 2 & 0,14 \\
\hline 2. & Conflict management in fish farmers groups was still weak & 0,10 & 2 & 0,20 \\
\hline 3. & $\begin{array}{l}\text { The network of fish farmers groups contribution were getting more } \\
\text { complex }\end{array}$ & 0,09 & 3 & 0,27 \\
\hline 4. & Group institutions were not in accordance with their functions and roles & 0,09 & 3 & 0,27 \\
\hline \multirow[t]{2}{*}{5.} & Group dynamics were not properly accommodated & 0,09 & 2 & 0,18 \\
\hline & Total & 1,00 & & 2,62 \\
\hline
\end{tabular}

Based on the IFAS (internal factor analysis summary) and EFAS (external factor analysis summary), a SWOT matrix was made to determine the problem-solving strategy for each SWOT parameter/category. The strategy was generated by optimizing strengths with opportunities (SO), namely taking advantage of opportunities to overcome weaknesses (WO), using strengths to suppress threats (ST), eliminating weaknesses and threats (WT) [11]. The SWOT matrix concludes, there were three strategies to improve the performance of fish farmers groups in Muntilan Sub District, Magelang Regency, namely 1) Mentoring activities to the fish farmers in accessing technology to improve their knowledge and attitudes, 2) Developing groups collaborate with the financial and marketing support institutions and 3) Strengthening communication networks between many fisheries groups [5]. 
Table 3. SWOT matrix strategy.

\begin{tabular}{|c|c|c|}
\hline \multirow[b]{3}{*}{ EKSTERNAL FACTORS } & Strengths (S) & Weaknesses (W) \\
\hline & $\begin{array}{l}\text { 1. Potential for human resource } \\
\text { development was quite high } \\
\text { 2. Sufficient number of fish farmers } \\
\text { to be developed } \\
\text { 3. A lot of fish farmers groups have } \\
\text { been formed } \\
\text { 4. Sufficient experience in the } \\
\text { fisheries business of the fish } \\
\text { farmers } \\
\text { 5. The area for fish farming } \\
\text { development was still wide }\end{array}$ & $\begin{array}{l}\text { 1. Insufficient infrastructure } \\
\text { 2. } \begin{array}{l}\text { Management, group administration, } \\
\text { motivation to collaboration and }\end{array} \\
\text { participation were still low } \\
\text { 3. The number of extension workers were } \\
\text { not sufficient } \\
\text { 4. Interests in groups were still low } \\
\text { 5. } \begin{array}{l}\text { Relationship between groups and } \\
\text { institutions supporting fisheries was } \\
\text { still low }\end{array}\end{array}$ \\
\hline & & \\
\hline Opportunities (O) & SO-Strategy & WO-Strategy \\
\hline $\begin{array}{l}\text { 1. Consumer interests to the fisheries } \\
\text { business results were quite high } \\
\text { 2. Access to increase knowledge and } \\
\text { skills in fisheries technology for the } \\
\text { fish farmers were wide open } \\
\text { 3. Financial and marketing institutions } \\
\text { support were quite high } \\
\text { 4. Commodities of freshwater fish } \\
\text { produced were easy to obtain } \\
\text { 5. Collaboration network between many } \\
\text { fisheries groups were open well }\end{array}$ & $\begin{array}{l}\text { 1. Mentoring activities to the fish } \\
\text { farmers groups in accessing } \\
\text { technology to improve their } \\
\text { knowledge and attitudes } \\
\text { 2. Developing fish farmers groups } \\
\text { collaboration with the financial } \\
\text { and marketing support } \\
\text { institutions } \\
\text { 3. Strengthening communication } \\
\text { networks with many other fish } \\
\text { farmers groups }\end{array}$ & $\begin{array}{l}\text { 1. Facilitation to the infrastructure grant } \\
\text { for fish farmers groups } \\
\text { Mentoring activities in management } \\
\text { and administration of fish farmers } \\
\text { groups and accessing to fisheries } \\
\text { technology information } \\
\text { 3. Sustainable fisheries extension } \\
\text { activities to increase the interests and } \\
\text { capacity of the fish farmers } \\
\text { 4. Facilitation of the fish farmers groups } \\
\text { with the fisheries support institutions }\end{array}$ \\
\hline Threats (T) & ST-Strategy & WT-Strategy \\
\hline $\begin{array}{l}\text { 1. Group independence was hampered } \\
\text { by regulation } \\
\text { 2. Conflict management in fish farmers } \\
\text { groups was still weak } \\
\text { 3. The network of fish farmers groups } \\
\text { contribution were getting more } \\
\text { complex } \\
\text { 4. Group institutions were not in } \\
\text { accordance with their functions and } \\
\text { roles } \\
\text { 5. Group dynamics were not properly } \\
\text { accommodated }\end{array}$ & $\begin{array}{l}\text { 1. Mentoring activities of the roles } \\
\text { and functions of the fish farmers } \\
\text { groups } \\
\text { 2. Creating the various agreements } \\
\text { with another fish farmers groups } \\
\text { to form a strong groups network } \\
\text { 3. Mentoring activities to } \\
\text { strengthens the capacity of fish } \\
\text { farmers groups that have been } \\
\text { formed }\end{array}$ & $\begin{array}{l}\text { 1. Mentoring activities on the importance } \\
\text { of conflict management in fish farmers } \\
\text { groups } \\
\text { 2. Socialization of the fisheries } \\
\text { regulations to the fish farmers groups } \\
\text { Mentoring activities from the fisheries } \\
\text { extension workers so that the dynamics } \\
\text { in the fish farmers groups can be used } \\
\text { to increase the motivation and } \\
\text { participation of its members }\end{array}$ \\
\hline
\end{tabular}

Achievement of group performance was the result of individual efforts in fish farmers groups in carrying out their primary tasks so that they can provide results according to the provisions of the groups [10]. In measuring the performance of a group, can be used the gap analysis to estimate that the smaller gap was the better performance [13]. In this case, the fish farmers group's performance can be improved by choosing the SO (Strengths-Opportunities) strategy, referring to the results of the analysis on the SWOT strategy matrix.

\section{Conclusion}

Infrastructure, fisheries extension performance, a collaboration of fish farmers in groups, and the interests of the fish farmers were the key factors to influence the growth and development of the fish farmers groups. The group, performance development strategy, were carried out by improving the performance of group roles and functions through mentoring and facilitation. Strengths-Opportunities (SO) was the chosen strategy for improving fisheries extension performance of the fish farmers groups in Muntilan Sub District. The strategy included mentoring activities to the fish farmers groups in accessing technology to enhance their knowledge and attitudes, developing fish farmers groups collaboration with the financial and marketing support institutions, and strengthening communication networks with many other fish farmers groups.

\section{Acknowledgements}

We want to express our sincere acknowledgments to the Director of Jakarta Technical University of Fisheries, the Head of the Livestock and Fisheries Service of Magelang Regency, the Head of the Muntilan Subdistrict, the Fisheries Extension Workers of the Muntilan Subdistrict, Another Department which related with the data of fisheries in 
Magelang Regency, all respondents from the Muntilan Subdistrict fish Farmers groups and another stakeholder. They have assisted in the completion of this research.

\section{References}

1. A. Harsono P, Sos. Hum. 12, 2 (2008)

2. A.K. Al Munif, Skripsi, Jakarta (ID): STP Jakarta, (2019)

3. Disdukcapil Kabupaten Magelang, Annual report (in Bahasa Indonesia) (Disdukcapil, Magelang, 2018)

4. D. Jatnika, K. Sumantadinata, N.H. Panjaitan, Manajemen IKM. 9, 1 (2014)

5. F. Rangkuti, SWOT analysis techniques to dissect business cases (in Bahasa Indonesia) (Gramedia Pustaka Utama, Jakarta, 2017)

6. Google Maps. Muntilan district map, https://maps.google.co.id.(2021)

7. I.N. Sumerta, Aquatic resources management (in Bahasa Indonesia) (IPB Press, Bogor, 2013)

8. J.A. Putri, T. Yuniarty, I.J.P. Dewi, JPPIK. 13, 2 (2019)

9. Badan Pusat Statistik, Muntial District in number (in Bahasa Indonesia) (BPS, Magelang, 2018)

10. Y.T. Keban, Six strategic dimensions of public administration, concepts, theories and issues (in Bahasa Indonesia) (Gava Media, Yogyakarta, 2004)

11. L.Yunus, M. Ramli, Yusnaeni, M.A. Limi, IJSTAS. 2, 1 (2015)

12. M.A. Rimmer, K. Sugama, D. Rakhmawati, R. Rofiq, R.H. Habgood, Rev Aquac. 5, 125 (2013)

13. M. Rizal, B. Wiryawan, S.H. Wisudo, I. Solihin, Mar. Fish. 8, 1 (2017)

14. P. K. Arieska, N. Herdiani, J. Stat. 6, 2 (2018)

15. Keputusan Menteri Kelautan Dan Perikanan Nomor 14 Tahun 2012. General guidelines for the growth and institutional development of key fishery actors (in Bahasa Indonesia), www.kkp.go.id. (2012)

16. Sugiono, Metode penelitian kuantitatif, kualitatif, dan $R \& D$ (Penerbit Alfabeta, Bandung, 2010)

17. T.P. Pangesti, T.W. Nurani, E.S. Wiyono, Mar. Fish. 2, 2 (2011)

18. Y.H. Rahmawan, R.R. Hakim, G.A. Sutarjo, IJOTA. 3, 1 (2020)

19. Z. Amin, International Seminar on Promoting Local Resources for Food and Health, 360-364 (2015) 